\title{
Environmental Management of Waste Based on Road Construction Materials
}

\author{
Damijan Koletnik $^{1}$, Rebeka Lukman ${ }^{1}$ and Damjan Krajnc ${ }^{2}$ \\ ${ }^{I}$ Nigrad d.d., Utility Company, R\&D Department, Slovenia \\ ${ }^{2}$ University of Maribor, Faculty of Chemistry and Chemical Engineering, Slovenia
}

crossref $\mathrm{http}: / / \mathrm{dx}$. doi.org/10.5755/j01.erem.59.1.681

(received in September, 2011, accepted in March, 2012)

In 2008 the European Council adopted a revised framework for waste management in the EU, with an objective to encourage recycling and reuse of waste, in order to reduce landfills and potential environmental emissions. This framework also sets new recycling targets for construction and demolition waste by 2020 , suggesting that at least $70 \%$ of the waste should be recycled.

Nigrad d.d. is a utility company providing services to several municipalities in North-East Slovenia. These services include repairs to public roads and pavements. This paper examines the origin, amount and fraction of construction waste produced, identifying current waste management practices. Based on the state-of-the art study new approaches are to be proposed, which will make it possible to decrease environmental impacts and costs, when providing public services and establishing sustainable service systems. To reach this objective a life-cycle analysis of the existing service has been carried out, which will help identify the system parts that have the most significant impact on the environment.

Keywords: Life cycle assessment, industrial ecology, utility company, construction waste.

\section{Introduction}

Waste is an environmental, economic, social, and political challenge to the EU, as well as to global society, due the fact that waste volumes continue to grow (European Commission 2005). For example, the European Commission reports that huge amounts of waste are generated in the activities such as manufacturing (360 Mt/a), or construction (900 Mt/a), having a significant impact on the environment, contributing to the climate change and losses of material (European Commission 2010). Thus, in 2008 the European Council adopted a revised framework for waste management in the EU, with an objective to encourage recycling and reuse of waste, in order to reduce landfill, environmental impact, and dependence on imported raw materials. Moreover, this framework sets new recycling targets for construction and waste demolition by 2020 , suggesting that at least $70 \%$ of the waste should be recycled.

In an effort to contribute to the greening of service systems, this paper discusses the introduction of the life cycle assessment (LCA) of service processes to a utility company Nigrad d.d. in Slovenia regarding the construction waste generated in public traffic areas, e.g. in asphalt roads and pavements repair, and further usage of that waste as a secondary raw material.

\section{Case Study}

An estimated quantity of construction waste produced in Slovenia is around 2 million tons annually, meaning around a ton per capita, whose $300-400 \mathrm{~kg}$ belongs to the residues of road 
construction (Alič 2011). A case study investigates a service of road maintenance regarding the construction waste provided by Nigrad d.d., which includes demolition of road that needs to be repaired, processing the construction waste produced, and, finally, construction of new parts of roads and pavements. Construction waste that emerges within the company (Nigrad d. d.) consists of the following fractions: concrete, bitumen mixtures, soil, stones and rocks, bricks, and mixed construction waste. Available data are represented in Table 1.

Table 1. Mass and fraction of construction waste produced within Nigrad d.d. in 2010

\begin{tabular}{|c|c|c|}
\hline Construction waste & Mass (t) & Fraction in \% \\
\hline Concrete & 169 & 2 \\
\hline Bitumen mixtures & 7260 & 94 \\
\hline Soil, stone, rocks & 306 & 4 \\
\hline TOTAL & 7735 & 100 \\
\hline
\end{tabular}

\section{Methods}

The LCA has been used to identify the environmental performance of the studied system.
The LCA is a powerful and well suited set of tools for identifying, quantifying, and evaluating potential environmental burdens of products, processes, and services in all stages of their life cycle and has become more systematic and robust over the past three decades (Jeswani et al. 2010, EPA 2010; Rebitzer et al. 2004). The LCA used in this study for evaluating environmental impacts is based on the ISO series 14000 (ISO 2006 a, b). The LCA methodology for environmental impacts assessment used in this research is based on the ISO 14040 and 14044 series (ISO, $2006 \mathrm{a}, \mathrm{b}$ ). The study has been performed using the LCA software GaBi 4 Professional ${ }^{\circledR}$ (PE International 2008) and Ecoinvent database v2.1 (Frischknecht et al. 2007)

The objective of this study is to carry out a screening LCA in order to estimate the life cycle environmental impacts of the waste generated by the service of repairing public road and pavements. Furthermore, processes in the system with a major environmental impact are to be identified. The functional unit is waste generated for one 100 meter long lane, based on traditional road structure in the urban area (Fig. 1).

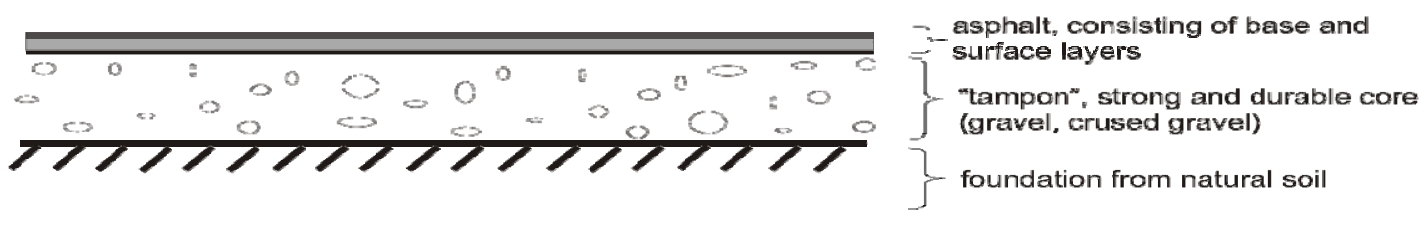

Fig. 1. A simplified road structure.

The following activities have been included into the system boundary:

- Demolition of existing road;

- Processing of waste obtained from demolition;

- Construction of new road.

The primary data such as waste generation, equipment, and materials needed for a road demolition/construction have been provided by the Nigrad company from the different internal data. For example, waste generation from the Evidence lists, that have to be filled out and published once a year to the Slovenian Environmental Agency (SEA 2010), the equipment and materials needed have been outsourced from the internal accounting office. The secondary data needed for the LCA study have been outsourced from the Ecoinvent database (Frischknecht et al. 2007). The Ecoinvent data base is the world leading database with consistent and transparent, up-to-date Life Cycle Inventory (LCI) data, with more than 4000 LCI datasets. High-quality generic LCI datasets are based on industrial data and have been compiled by internationally renowned research institutes and LCA consultants (Ecoinvent 2012). There have been some assumptions in the study, such as road transport as a major means of transport of construction waste from demolition of roads as well as materials for road construction. Furthermore, the study considers that more than $90 \%$ of bitumen mixtures are recycled or re-used for roadsides, and that $50 \%$ of soil, stones, and rocks are re-used for a "tampon" - a durable core of the road.

\section{Results and discussion}

The environmental impacts have been calculated following the "CML (Center of Environmental Science of Leiden University) 2001" (Guinée 2001 a, b; Frischknecht et al. 2007).

The results shown in Figs. 2 and 3 indicate that the service of maintenance of the public road (demolition, waste processing and construction of a new road) has the most significant impact on human toxicity (HT), followed by acidification potential (AP), global warming potential (GWP), eutrophication potential (EP), and photochemical ozone creation potential (POCP). The 'hot spot' in the system, with the largest contribution to all the impacts, is road construction (see Fig. 4). It contributes the most to the terrestric ecotoxicity potential (TEP). Waste processing is a second largest contributor and has a significant impact on acidification, eutrophication, global warming, and human toxicity potentials. Demolition of road contributes to all impact categories, and has the most significant impacts in the same categories as waste processing. 


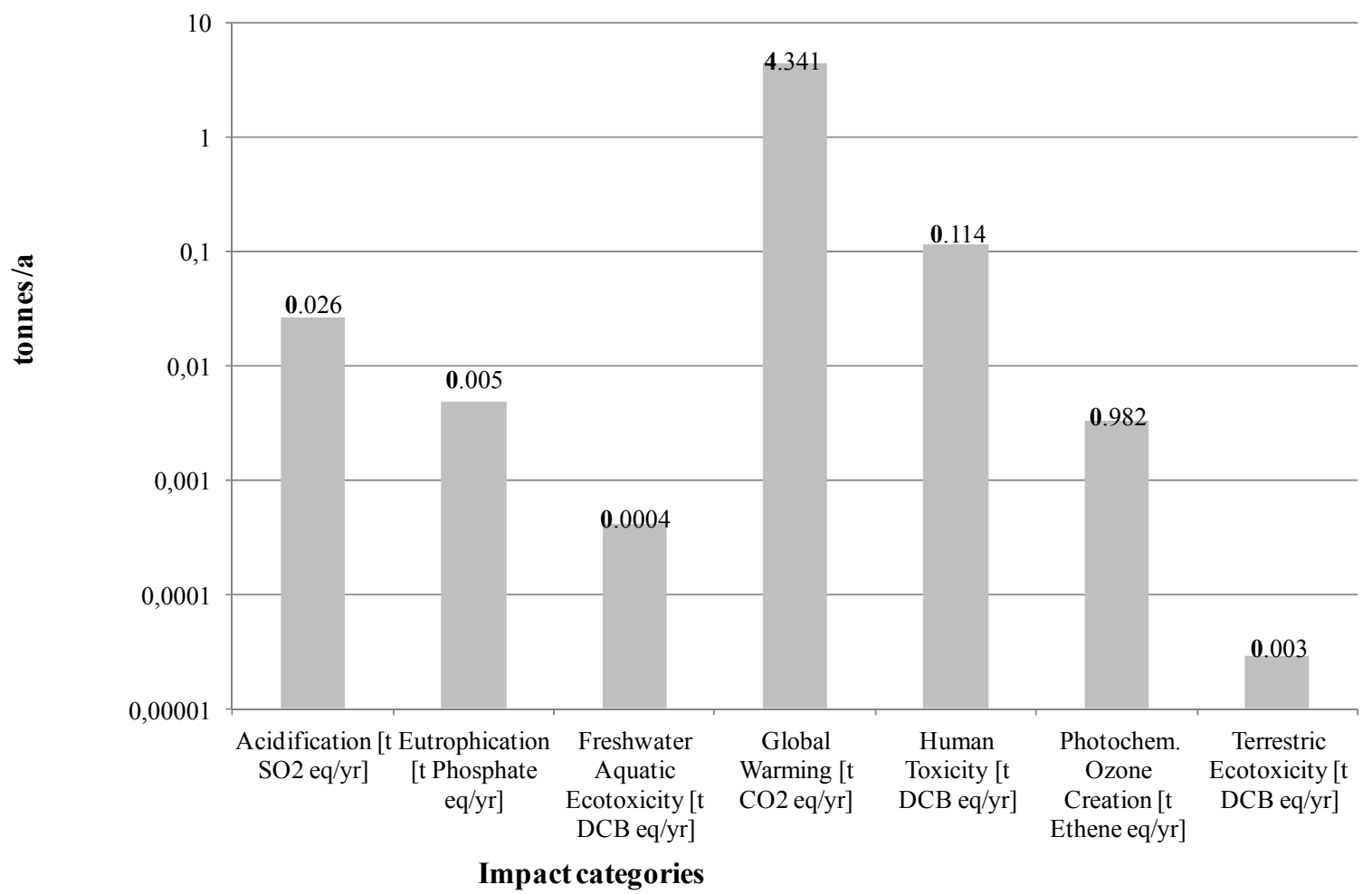

Fig. 2. Environmental impacts of the system considered (demolition of existing road, processing of waste obtained from

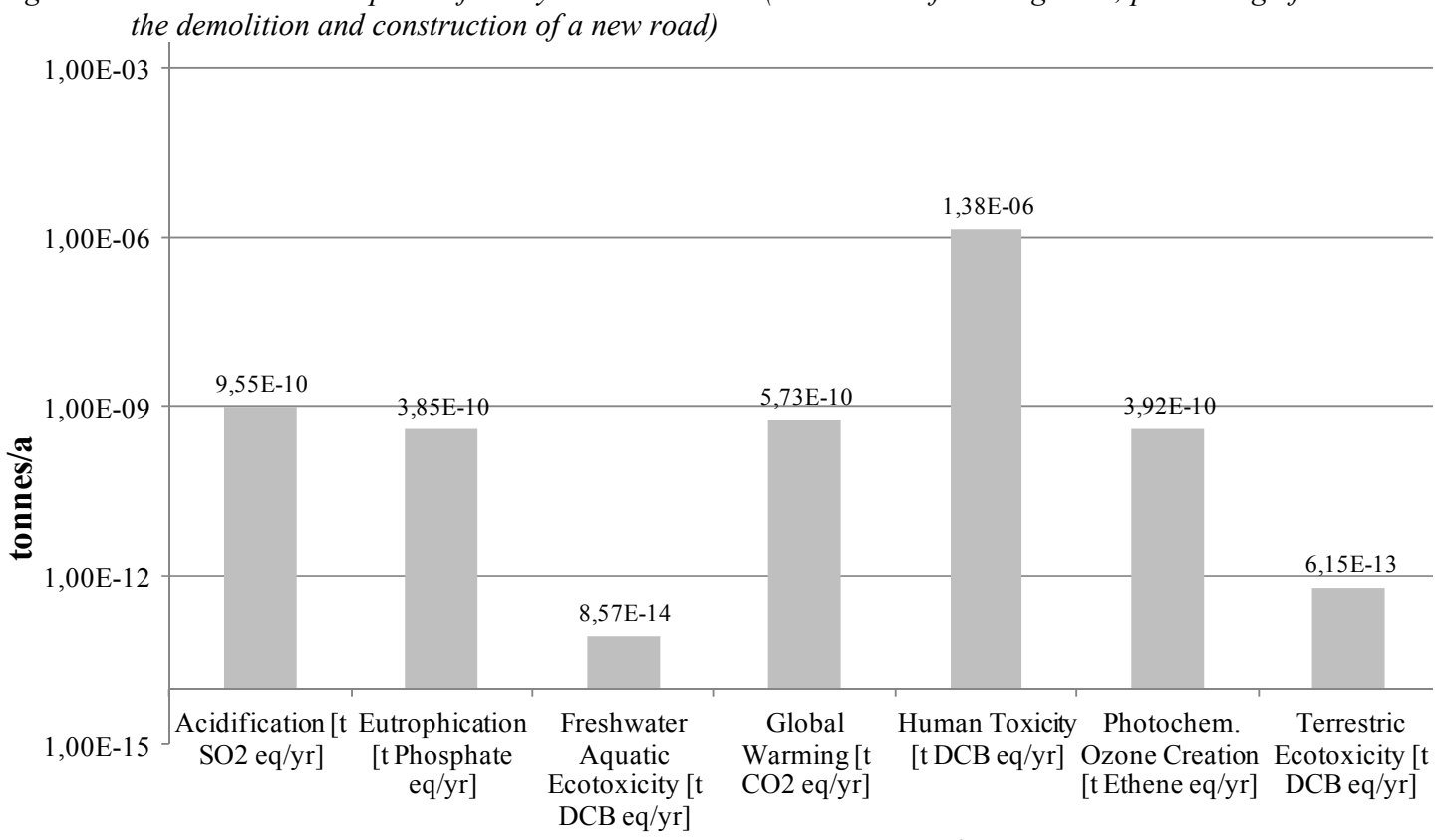

\section{Impact categories}

Fig. 3. Normalized environmental impacts (normalized by the factors for Western Europe) of the system considered (demolition of the existing road, processing of waste obtained from demolition and construction of a new road)

\section{Conclusions}

Our study has evaluated the environmental performance of the repair/maintenance of public road service at the Nigrad company, Slovenia, using a life cycle approach. The results suggest that the service provided has the most significant environmental impacts on human toxicity (HT), followed by acidification potential (AP), and global warming potential (GWP). The main contributor to all the impacts is a process of road construction, followed by waste processing, and demolition of a road.

In order to reduce overall environmental impacts, various improvement options for the road construction as well as for the waste processing can be considered, such as re-usage and re-construction of 
materials that can be integrated into road systems, remanufacturing of excavation materials (e.g. gravel), and re-usage of old asphalts. Another possibility to reduce the environmental impacts of the service provided by the company could be establishment of an efficient system of waste management, assurance of control and inventory, evidence of subjects in a "construction waste supply chain". Undoubtedly, further studies are required, therefore, our future work will focus on the LCA of improved and alternative processes (e.g. re-usage of old asphalt), agreeable to the principles of industrial ecology.

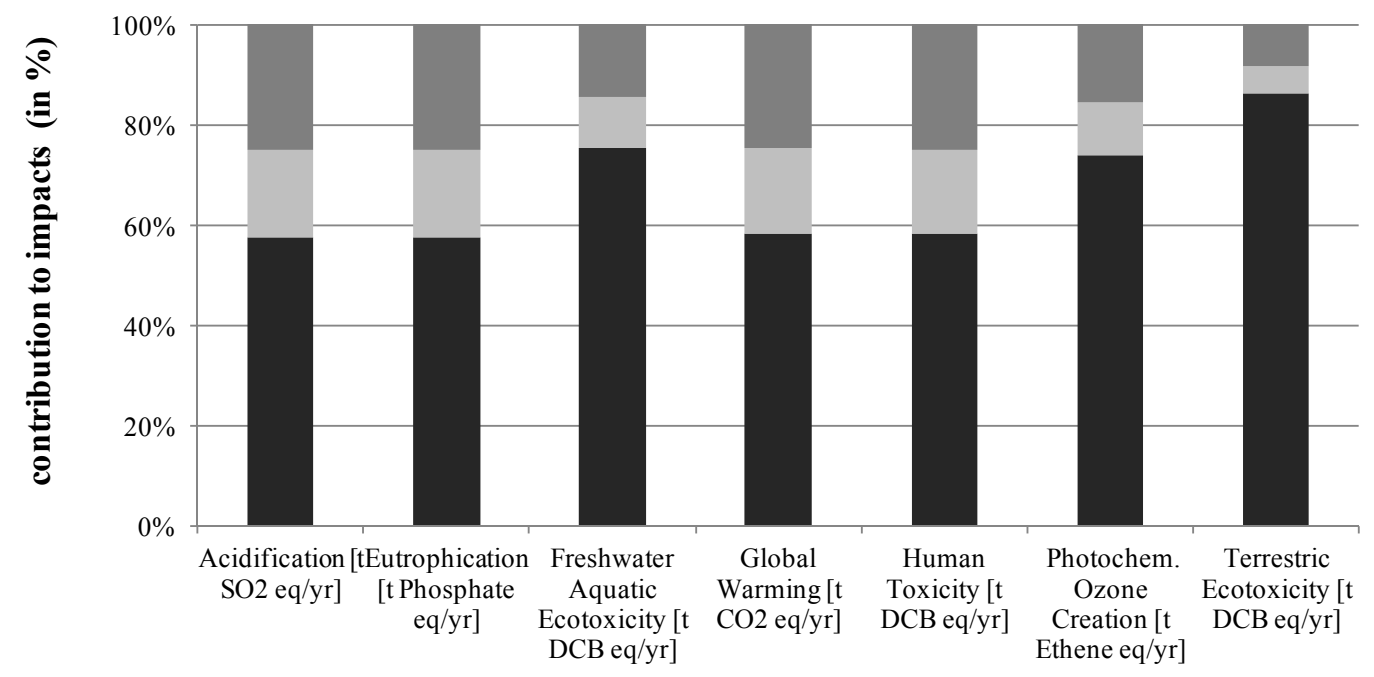

- Road construction $\quad$ Demolition Processing of waste

Fig. 4. Relative contributions of different activities (demolition of the existing road, processing of waste obtained from demolition and construction of a new road) to the total environmental impacts

\section{Acknowledgements}

Rebeka Lukman would like to thank the Slovenian Research Agency for financing her research within the financial program for postdoctoral researchers (Project No. Z2-3681-2886) and Nigrad Utility Company for providing the necessary data for this study.

\section{References}

ALIČ K (2011). Legislation and quantity of construction waste in Slovenia and Abroad, University of Ljubljana, Faculty of Civil and Geodetic Engineering.

ECOINVENT (2012). Ecoinvent database, retrieved from: http://www.ecoinvent.org/database/

EPA (2010). Life cycle assessment, retrieved from: http://www.epa.gov/nrmrl/lcaccess/

EUROPEAN COMMISSION. 2005. Communication from the Commission to the Council, the European Parliament, the European Economic and Social Committee, and the European Committee of the Regions.

EUROPEAN COMMISSIONS. 2010. Being wise with waste: the EU's approach to waste management. Luxembourg: Publication Office of the European Union.

FRISCHKNECHT R, JUNGBLUTH N (Eds.), ALTHAUS H-J, BAUER C, DOKA G, DONES R, HISCHIER R, HELLWEG S, HUMBERT S, KÖLLNER T, LOERINCIK Y, MARGNI M, NEMECEK T. 2007. Implementation of Life cycle impact Assessment methods. Data v2.0, Ecoinvent report No. 3. Swiss Centre for Life Cycle Inventories, Dübendorf.

GUINÉE JB, (FINAL EDITOR), GORRÉE M, HEIJUNGS R, HUPPES G, KLEIJN R, DE KONING A,
VAN OERS L, WEGENER SLEESWIJK A, SUH S, UDO DE HAES HA, DE BRUIJN $\mathrm{H}$, VAN DUIN R, HUIJBREGTS MAJ, LINDEIJER E, ROORDA AAH AND WEIDEMA BP. 2001a. Life cycle assessment; An operational guide to the ISO standards; Parts 1 and 2 . Ministry of Housing, Spatial Planning and Environment (VROM) and Centre of Environmental Science (CML), Den Haag and Leiden, The Netherlands, retrieved from: http://www.leidenuniv.nl/cml/ssp/projects/lca2/lca2.html.

GUINÉE JB, (FINAL EDITOR), GORRÉE M, HEIJUNGS R, HUPPES G, KLEIJN R, DE KONING A, VAN OERS L, WEGENER SLEESWIJK A, SUH S, UDO DE HAES HA, DE BRUIJN $\mathrm{H}$, VAN DUIN R, HUIJBREGTS MAJ, LINDEIJER E, ROORDA AAH AND WEIDEMA BP. 2001b. Life cycle assessment; An operational guide to the ISO standards; Part 3: Scientific Background. Ministry of Housing, Spatial Planning and Environment (VROM) and Centre of Environmental Science (CML), Den Haag and Leiden, The Netherlands, retrieved from: http://www.leidenuniv.nl/cml/ssp/projects/lca2/lca2.html.

ISO. 2006a. 14040 - Environmental Management Life cycle assessment - Principles and framework. Geneva. Switzerland.

ISO. 2006b. 14044 - Environmental Management Life cycle assessment - Requirements and Guidelines. Geneva. Switzerland.

JESWANI HK, AZAPAGIC A, SCHEPELMANN P and RITTHOFF M 2010. Options for broadening and deepening the LCA approaches. Journal of Cleaner Production 18: 120-127. http://dx.doi.org/10.1016/j.jclepro.2009.09.023

PE INTERNATIONAL.2008., retrieved from: http://www.gabi-software.com/ 
REBITZER G, EKVALL T, FRISCHKNECHT R, HUNKELER D, NORRIS G, RYDBERG T, SCHMIDT WP, SUH S, WEIDEMA BP, PENNINGTON DW. 2004. Life cycle assessment. Part 1: Framework, goal and scope definition, inventory analysis, and applications. Environment International 30: 701-720. http://dx.doi.org/10.1016/j.envint.2003.11.005

$$
\text { SLOVENIAN ENVIRONMENTAL AGENCY (SEA) }
$$

(2010). Annual report, retrieved from: http://www.arso.gov.si/varstvo\%20okolja/odpadki/obrazci/o brazec\%20ODP-Z\%202011.pdf (in Slovene)
MSc Damijan Koletnik - CEO Deputy, Nigrad d.d.

Main research area: Sustainable energy usage, supply chains, logistics

Address: Zagrebška 30, SI-2000 Maribor

Tel.: $\quad+38624500304$

E-mail: damijan.koletnik@nigrad.si

Dr. Rebeka Lukman - Nigrad d.d., Research and Development department.

Main research area: life cycle assessment, sustainable consumption and production, education for sustainable development

Address: Zagrebška 30, SI-2000 Maribor

Tel.: $\quad+38624500391$

E-mail: $\quad$ rebeka.lukman@nigrad.si

Assoc. prof. dr. Damjan Krajnc - Laboratory for Process Systems Engineering and Sustainable Development, University of Maribor, Faculty of Chemistry and Chemical Engineering

Main research area: life cycle assessment and costing, industrial ecology, sustainable consumption and production

Address: $\quad$ Smetanova 17, SI-2000 Maribor

Tel.: + + 38622294472

E-mail: $\quad$ damjan.krajnc@uni-mb.si 